\title{
Peran Guru Dalam Peningkatan Kualitas Belajar Peserta Didik Pada Pembelajaran Daring Di Madrasah Ibtidaiyah
}

\author{
Tri Budi Wulandani \\ IAIN Jember \\ tb.wulandani@gmail.com \\ Rif'an Humaidi \\ IAIN Jember \\ humaidirifan79@gmail.com
}

DOI: 10.35719/educare.v2i1.47

\begin{abstract}
In the teaching and learning process, teachers are required to be able to carry out their role to the fullest as a motivator and initiator in an effort to maintain and at the same time increase the enthusiasm of students to learn. Especially in the Covid-19 pandemic situation which requires educational institutions to carry out online learning. This study aims to discuss the teacher's role as a motivator and the teacher's role as an initiator in improving the quality of student learning in online learning at Madrasah Ibtidaiyah Ma'arif Condro Jember. This research uses qualitative research methods and the type of research is a case study. Data collection techniques using observation, interviews and documentation. The validity of the data using source triangulation and technical triangulation. Meanwhile, data analysis uses data condensation, data presentation and verification/conclusion. The results of this study indicate: 1) The teacher's role as a motivator in improving the quality of learning in online learning, namely: providing opportunities for students to play an active role in learning, providing reinforcement, praise or verbal appreciation, teachers listening to students' concerns and wishes to bond. good relationship between teachers and students. 2) The role of the teacher as an initiator in improving the quality of learning in online learning, namely: utilizing information and communication technology such as Whatsapp, Facebook, Google Meet and Google Form.
\end{abstract}

Keywords: Teacher Role; Quality of Learning; Online Learning 


\begin{abstract}
Abstrak
Dalam proses belajar mengajar, guru dituntut untuk mampu melaksanakan perannya secara maksimal menjadi motivator dan inisiator dalam upaya menjaga dan sekaligus meningkatkan semangat belajar peserta didik. Terlebih dalam situasi pandemi Covid-19 yang menuntut lembaga pendidikan untuk melaksanakan pembelajaran secara Daring. Penelitian ini bertujuan untuk membahas tentang peran guru sebagai motivator dan peran guru sebagai inisiator dalam meningkatan kualitas belajar peserta didik pada pembelajaran daring di Madrasah Ibtidaiyah Ma'arif Condro Jember. Penelitian ini menggunakan metode penelitian kualitatif dan jenis penelitiannya adalah studi kasus. Teknik pengumpulan data menggunakan observasi, wawancara dan dokumentasi. Keabsahan data menggunakan triangulasi sumber dan triangulasi teknik. Sedangkan analisis data menggunakan kondensasi data, penyajian data dan verifikasi/kesimpulan. Hasil penelitian ini menunjukkan: 1) Peran guru sebagai motivator dalam meningkatkan kualitas belajar pada pembelajaran daring yaitu: memberikan kesempatan kepada peserta didik untuk berperan aktif dalam pembelajaran, memberikan penguatan, pujian atau apresiasi secara verbal, guru mendengarkan keresahan dan keinginan peserta didik agar terjalin ikatan yang baik antara guru dan peserta didik. 2) Peran guru sebagai inisiator dalam meningkatkan kualitas belajar pada pembelajaran daring yaitu: memanfaatkan teknologi informasi dan komunikasi seperti Whatsapp, Facebook, Google Meet dan Google Form.
\end{abstract}

\title{
Kata Kunci:Peran Guru; Kualitas Belajar; Pembelajaran Daring
}

\section{PENDAHULUAN}

Pendidikan merupakan faktor utama dalam pembentukan kualitas manusia, membentuk baik dan buruknya pribadi manusia dalam ukuran normatif. Mengingat tentang hal itu, pemerintah terus berinovasi secara serius dalam menangani bidang pendidikan, sebab dengan sistem pendidikan yang baik diharapkan dapat mencetak generasi penerus bangsa yang berkualitas dan mampu menyesuaikan diri dalam untuk bermasyarakat, berbangsa dan bernegara. Hal ini juga sejalan dengan konsep Islam, yang menaruh perhatian serius pada masalah pendidikan. Pentingnya peran seorang pendidik menjadi fokus utama dalam penyampaian informasi yang tepat dan kredibel. Peran guru juga berdampak cukup besar terhadap 
keberlangsungan pembelajaran peserta didik di kelas maupun di luar kelas. Guru selayaknya memberi pengajaran dan contoh perilaku yang baik, karena setiap apa yang disampaikan dan dilakukan oleh guru akan memberi perubahan signifikan terhadap peserta didik.

Peran guru bisa diimplementasikan dengan baik apabila adanya interaksi tatap muka antara guru dan peserta didik di sekolah. Namun, setelah merebaknya wabah Covid-19 di Wuhan pada akhir 2019, dan menimbulkan dampak yang mulai terasa di Indonesia khususnya Kementrian Pendidikan dan Kebudayaan serta Kementrian Agama. Pembelajaran daring menjadi satu alternative dalam menghambat penyebaran virus Covid-19 di klaster pendidikan. Madrasah Ibtidayah Ma'arif Condro adalah salah satu lembaga yang menerapkan pembelajaran daring pada masa darurat Covid 19.

Madrasah Ibtidaiyah Condro ini adalah madrasah swasta yang terletak di daerah perkotaan kabupaten Jember. Sebagai madrasah swasta yang berada di tengah kota, peran gurunya sangat tampak dalam memotivasi dan menciptakan inisiasi untuk mengupayakan peserta didik agar tidak kehilangan motivasi belajar pada proses pembelajaran daring dalam situasi pandemi Covid-19. Pemberian motivasi secara verbal atau inisiasi pengembangan pembelajaran agar lebih menarik dan tidak membosankan menjadi prioritas utama untuk menciptakan kualitas pembelajarannya. Atas dasar tersebut, maka peneliti tertarik untuk mengkaji dan meneliti lebih dalam tentang "Peran Guru Dalam Meningkatkan Kualitas Belajar Pada Pembelajaran Daring".

Terdapat beberapa penelitian terdahulu yang sama-sama membahas mengenai cara meningkatkan kualitas belajar. Perbedaan penelitian ini dengan beberapa penelitian terdahulu yang paling mencolok terletak pada focus penelitian, objek penelitian, lokasi penelitian dan tahun penelitian. Hasil penelitian ini diharapkan mampu menambah wawasan keilmuan bagi peserta didik serta masyarakat pada umumnya. 


\section{METODE PENELITIAN}

Metode yang digunakan dalam penelitian ini adalah metode penelitian kualitatif dengan pendekatan kualitatif deskriptif. Jenis penelitian adalah studi kasus. Lokasi penelitian terletak di Kabupaten Jember, tepatnya di Madrasah Ibtidaiyah Ma'arif Condro yang terletak di Jl. Gajah Mada XIX No.13 Kecamatan Kaliwates, Kabupaten Jember, Provinsi Jawa Timur. Penelitian ini lebih difokuskan kepada peran guru kelas VB terkait perannya sebagai motivator dan inisiator dengan jumlah peserta didik sebanyak 26 peserta didik yang terdiri dari 12 peserta didik laki-laki dan 14 peserta didik perempuan. ${ }^{1}$ Subjek penelitian terdiri dari Kepala Madrasah, Guru Kelas VB, Peserta didik dan Orang Tua kelas VB. Teknik pengumpulan data menggunakan observasi, wawancara dan dokumentasi. Keabsahan data menggunakan triangulasi sumber dan triangulasi teknik. Adapun analisis data menggunakan model Miles, Huberman dan Saldana yaitu menggunakan condensasi data, penyajian data dan verifikasi/kesimpulan.

\section{HASIL DAN PEMBAHASAN TEMUAN}

\section{Peran Guru Sebagai Motivator dalam Meningkatkan Kualitas Belajar} Peserta Didik Pada Pembelajaran Daring di Madrasah Ibtidaiyah

Berdasarkan data lapangan yang diperoleh melalui observasi, wawancara dan dokumentasi di Madrasah Ibtidaiyah Ma'arif Condro Jember, didapati bahwa guru merupakan tenaga profesional yang memiliki beberapa kemampuan khusus yang harus dilatih secara terus menerus. Tidak sembarang orang bisa menjadi guru yang profesionl, sebagaimana pernyataan M. Uzer Usmani dalam bukunya yang menyatakan guru merupakan jabatan atau profesi yang memerlukan keahlian khusus sebagai guru. Pekerjan ini tidak bisa dilakukan oleh sembarang orang yang tidak memiliki keahlian untuk melakukan kegiatan atau pekerjaan ini. Untuk menjadi guru sangat diperlukan syarat-syarat tertentu dan dengan

${ }^{1}$ Observasi Madrasah Ibtidaiyah Ma'arifCondro Jember 2020. 
memahami berbagai ilmu pengetahuan lainnya serta perlu pembinaan dan pengembangan melalui pendidikan dalam jangka waktu tertentu. ${ }^{2}$

Sebagai seorang profesional guru harus menjalani beberapa peranperan khusus dalam menghadapi peserta didiknya, salah satunya peran guru sebagai motivator. Peran guru sebagai motivator sangat dibutuhkan dalam meningkatkan kualitas belajar peserta didik. Sudirman A. M. menyatakan bahwa guru sebagai motivator adalah guru yang mampu menjadi pendorong dalam rangka meningkatkan gairah dan semangat belajar peserta didik. ${ }^{3}$ Senada dengan Cece Wijaya, dkk dalam bukunya yang menyebutkan guru sebagai motivator adalah guru yang harus memberikan motivasi belajar kepada peserta didik agar semangat belajar peserta didik tetap tinggi. ${ }^{4}$

Motivasi diberikan guna mempertahankan semangat belajar peserta didik dimasa pembelajaran daring. Umumnya, motivasi yang diberikan berupa kesempatan peserta didik untuk berperan aktif dalam pembelajaran. Hal ini sesuai dengan ciri-ciri pembelajaran yang berkualitas yang disampaikan oleh Suhana dengan menyatakan bahwa ciri-ciri belajar yang berkualitas menuntut keaktifan peserta didik dalam proses pembelajaran. Peserta didik tidak ditempatkan sebagai penerima bahan ajar yang diberikan oleh guru saja, melainkan sebagai subjek yang aktif melakukan proses berfikir, mencari, mengolah, menyimpulkan dan menyelesaikan masalah ${ }^{5}$.

Selain itu, motivasi yang diberikan berupa penguatan dan pujian atau apresiasi secara verbal yang diberikan guru melalui pesan teks Whatsapp pada akhir pemberian materi dan akhir pengoreksian tugas. Hal ini pun sesuai dengan pernyataan Slameto yang menyebutkan ada empat hal yang

\footnotetext{
${ }^{2}$ Moh. UzerUsmani, Menjadi Guru Profesional, (Bandung: Remaja Rosdakarya, 2001), 5 .

${ }^{3}$ Sudirman A.M., Interaksi dan Motivasi Belajar Mengajar, (Jakarta: Rajawali, 1990), 143.

${ }^{4}$ Cece Wijaya, dkk, Upaya Pembaharuan Dalam Pendidikan dan Pembaharuan dan Pengajaran, (Bandung: Remaja Rosdakarya, 1992),108.

${ }^{5}$ Hanifah Suhana dan Cucu, Konsep Strategi Pembelajaran, (Bandung: PT. Rafika Aditama, 2010), 93.
} 
dapat guru kerjakan dalam memberikan motivasi kepada peserta didik, yaitu $^{6}$ :

a. Membangkitkan dorongan kepada peserta didik untuk belajar.

b. Menjelaskan secara konkret kepada peserta didik apa yang dapat dilakukan pada akhir pengajaran.

c. Memberikan apresiasi terhadap prestasi yang dicapai sehingga dapat merangsang untuk mencapai prestasi yang lebih baik dikemudian hari.

d. Membentuk kebiasaan belajar yang baik.

e. Menjadi evaluator. Evaluasi diadakan untuk mengetahui tingkat keberhasilan dalam memberikan materi kepada peserta didik.

Tidak hanya itu, guru juga perlu mengetahui keresahan dan keinginan dari peserta didiknya selama mengikuti pembelajaran daring, karena hal ini dapat menjadi salah satu cara guru untuk dapat dekat dan mengenal peserta didiknya sehingga motivasi belajar dapat diberikan dengan mudah oleh guru ke peserta didik. Hal ini sesuai pernyataan Mulyana A. Z dalam bukunya yang menyebutkan beberapa peranan guru sebagai motivator adalah ${ }^{7}$ :

a. Guru harus bersikap terbuka kepada peserta didiknya yaitu melakukan tindakan yang mampu mendorong kemauan peserta didik untuk megungkapkan pendapatnya, menerima peserta didik dengan segala kekurangan dan kelebihannya, mau menanggapi.

b. Membantu peserta didik agar mampu mengembangkan dan memanfaatkan potensinya secara optimal.

c. Menciptakan hubungan yang serasi dan penuh kegairahan dalam interaksi belajar mengajar di kelas, dalam menunjukkan kegiatan antara lain, menangani perilaku peserta didik yang tidak diinginkan secara positif, menunjukkan kegairahan dalam megajar, murah senyum, mampu mengendalikan emosi, dan mampu bersifat proporsional sehingga

\footnotetext{
${ }^{6}$ Slameto, Belajar dan Faktor-faktor yang Mempengaruhinya, (Jakarta: Rineka Cipta, 2003), 95.

${ }^{7}$ Mulyana. A. Z., Rahasia Menjadi Guru Hebat, (Jakarta: Grasindo, 2010), 203.
} 
berbagai masalah pribadi dari guru itu sendiri dapat didudukkan pada tempatnya.

\section{Peran Guru Sebagai Inisiator Dalam Meningkatkan Kualitas Belajar}

\section{Pada Pembelajaran Daring di Madrasah Ibtidaiyah}

Peran guru sebagai inisiator sangat penting, perlunya ide-ide yang bervariatif dan kreatif dalam pelaksanaan pembelajaran sangat diperlukan agar mampu menunjang pembelajaran itu supaya daat berjalan dengan lancar. Sependapat dengan Sudirman A.M. yang menyatakan guru sebagai inisiator adalah guru yag dapat pencetus ide-ide dalam proses belajar mengajar. Menemukan hal-hal baru yang dapat menjadikan proses belajar mengajar menyenangkan dan optimal. ${ }^{8}$

Proses pembelajaran tidak bisa lepas dari keberadaan guru. Tanpa adanya guru pembelajaran akan sulit dilakukan, apalagi dalam rangka pelaksanaan pendidikan formal, guru menjadi pihak yang sangat vital. Guru memiliki peran yang paling atif dalam pelaksanaan pendidikan demi mencapai tujuan pendidikan yang hendak dicapai. Guru melaksanakan pendidikan melalui kegiatan pembelajaran dengan mengajar peserta didik.

Guru merupakan faktor penentu yang sangat dominan dalam pembelajaran pada umumnya, karena guru memegang peranan dalam proses pembelajaran, dimana proses pembelajaran merupakan inti dari proses pendidikan secara keseluruhan. Guru merupakan faktor penentu yang sangat dominan dalam pendidikan pada umumnya, karena guru memegang peranan dalam proses pembelajaran, dimana proses pembelajaran merupakan inti dari proses pendidikan secara keseluruha

Guru memerlukan berbagai cara agar pembelajaran tidak monoton dan membosankan dalam pembelajaran daring. Salah satunya dengan memanfaatkan teknologi informasi dan komunikasi dan media-media yang berkembang saat ini. Guru harus mampu memilih dan memilih media

\footnotetext{
${ }^{8}$ Sudirman A.M., Interaksi dan Motivasi Belajar Mengajar, 143.
} 
belajar yang mana yang mampu efektif jika digunakan untuk peserta didiknya. Guru harus mau mencoba dan mengembangkan dirinya agar mampu menciptakan pembelajaran yang nyaman, selayaknya pembelajaran tatap muka di kelas. Sebagaimana yang diugkapkan oleh Meda Yuliani dalam bukunya yang menyatakan pemanfaatan teknologi informasi sebagai sumber belajar dalam pembelajaran daring sangat diperlukan, terlebih disaat seperti ini mengharuskan paserta didik melakukan pembelajaran secara online atau daring. dalam pemanfaatan sumber belajar setiap hal ataupun sesuatu yang dapat dimanfaatkan peserta didik dalam melaksanakan pembelajaran merupakan sumber belajar dalam kondisi belajar online. ${ }^{9}$

Adanya ide-ide yang dapat meningkatkan kualitas peserta didik harus guru lakukan dengan memanfaatkan media atau aplikasi belajar lainnya. Guru terus berusaha dan berupaya mengembangkan cara mengajarnya dengan terus belajar menggunakan aplikasi-aplikasi belajar lainnya yang menunjang dan memudahkan dirinya dalam menyampaikan materi dan memudahkan peserta didiknya dalam memahami materi yang disampaikan.

Beberapa aplikasi yang dapat guru gunakan dalam pembelajaran daring ini antara lain Whatsapp, Facebook, Google Meet dan Google Form. Di antara aplikasi yang digunakan tersebut, terdapat aplikasi Whatsapp yang paling umum digunakan oleh masyarakat saat ini. pernyataan ini senada dengan pernyataan yang disampaikan Meda Yuliani yang menyebutkan Whatsapp merupakan aplikasi yang paling banyak diminati oleh masyarakat dalam berkomunikasi menggunakan internet. Aplikasi untuk melakukan percakapan baik dengan mengirim teks, suara maupun video. ${ }^{10}$

Aplikasi lainnya yang digunakan selain Whatsapp adalah aplikasi Google Meet. Aplikasi ini selayaknya aplikasi Zoom ini dapat melakukan siaran langsung/live streaming yang mampu memberikan sensasi tatap muka

\footnotetext{
${ }^{9}$ MedaYuliani, dkk, Pembelajaran Daring Untuk Pendidikan: Teori dan Penerapan, (Yayasan Kita Menulis, 2020), 88

${ }^{10}$ Yuliani, Pembelajaran Daring, 6.
} 
antara guru dan peserta didik selayaknya pembelajaran langsung di kelas. Dengan menggunakan aplikasi tatap muka seperi Google Meet ini, guru dapat berkomunikasi secara mudah dengan peserta didiknya dan peserta didik dapat bertemu dengan gurunya walaupun hanya melalui media online. Selain itu, guru dan peserta didik dapat belajar lebih banyak mengenai teknologi informasi dan komunikasi yang berkembang pada masa ini, sehingga menjadikan guru dan peserta didik melek teknologi.

Pada prinsipnya, pelakasanaam pembelajaran daring (dalam jaringan) dilakukan di lembaga pendidikan madrasah tetap mengacu pada prinsip kemandirian, keluwesan, mobilitas dan efisiensi. Selain itu, rencana pelaksanaan pembelajaran merupakan rancangan bagi guru dalam melaksanakan kegiatan yang diperuntukkan bagi anak untuk belajar dengan memanfaatkan teknologi seperti website, LMS, Whatsapp, dan lain-lain. ${ }^{11}$

Dalam penggunaan media apapun tentunya ada dampak untuk pembelajaran, ada beberapa dampak positif pembelajaran daring yang dapat di rasakan oleh guru maupun peserta didik, sebagaimana yag telah dipaparkan oleh Meda Yuliani sebagai berikut :

a. Manfaat pembelajaran daring / daring bagi guru, antara lain ${ }^{12}$ :

1) Guru dapat mengakses pengetahuan langsung memalui gawai yang digunakan

2) Pembelajaran tidak terfokus pada satu tempat dan waktu

3) Guru dapat membuat satu materi yang bisa diakses berulang-ulang oleh peserta didik

4) Lebih banyak belajar tentang aplikasi/media pembelajaran

5) Dapat mengerjakan lebih dari 1 pekerjaan sekaligus

6) Guru menjadi melek teknologi

\footnotetext{
${ }^{11}$ Abdul Karim dan Luluk Handayani. "Pengelolaan Open and Distance Learning Di TK Muslimat NU 41 Wuluhan Jember". GENIUS: Indonesian Journal of Early Childhood Education 1, no. 1 (June 2, 2020): 28. https://genius.iainjember.ac.id/index.php/gns/article/view/5.

${ }^{12}$ Yuliani, Pembelajaran Daring, 24-25.
} 
7) Guru dapat menciptakan pembelajaran yang kreati dan inovatif

b. Manfaat pembelajaran daring/daring bagi peserta didik, antara lain ${ }^{13}$ :

1) Peserta didik lebih mahir dalam ilmu teknologi (IT)

2) Peserta didik bisa mengulang-ulang materi pembelajaran yang dirasa belum dipahami

3) Waktu yang digunakan lebih singkat dan padat dari biasanya

4) Tidak terpaku hanya pada satu tempat

5) Menghemat biaya transportasi

6) Tanya jawab bersifat fleksibel

7) Melatih kemandirian dan tanggung jawab peserta didik

8) Penggunaan handphone akan lebih bermanfaat

9) Pengalaman baru dalam belajar

Aplikasi lain yang dapat digunakan dalam pemberian latihan soal yakni guru dapat menggunakan aplikasi Google Form. Aplikasi ini membantu guru dalam pelaksanaan ujian, baik ujian harian atau ujian tengah semester, dan latihan soal lainnya secara online melalui website yang telah guru siapkan untuk peserta didik. Aplikasi ini sangat membantu dan mendukug lancarnya sebuah ujian untutk peserta didik. Hal ini dapat membuktikan bahwa guru harus berupaya untuk mengambil tindakan ketika menemukan sebuah persoalan. Kepeduliannya mendorong untuk mengambil tindakan, tanpa berfikir gagal, guru tersebut terus berupaya menguasai keadaan melalui tindakan yang tepat demi memudahkan peserta didiknya dalam pelaksanaan pembelajaran daring.

Hal ini sesuai ciri-ciri guru sebagai inisiator yang dikemukakan oleh Leken Setyadi sebagai berikut ${ }^{14}$ :

a. Guru sebagai inisiator memiliki kecenderungan lebih aktif mengambil inisiatif tindakan tanpa harus menunggu perintah atasan.

\footnotetext{
${ }^{13}$ Yuliani, Pembelajaran Daring, 25-26.

${ }^{14}$ Leken Setyadi, Jadilah Guru Terbalik: Berfikir dan Bertindak Terbalik, (Ponorogo: Uwais Isnpirasi Indonesia, 2019),101.
} 
b. Guru sebagai inisiator memiliki sikap kepedulian lebih baik dibandingkan dengan guru biasa.

c. Guru sebagai inisiator tidak takut gagal, tidak takut disalahkan.

d. Guru sebagai inisiator lebih kreatif.

\section{SIMPULAN}

Berdasarkan temuan penelitian yang telah dibahas di atas, maka dapat disimpulkan sebagai berikut: (1) Peran guru sebagai motivator dalam meningkatkan kualitas belajar pada pembelajaran daring yaitu memberikan kesempatan kepada peserta didik untuk berperan aktif dalam pembelajaran, memberikan penguatan, pujian atau apresiasi secara verbal. Pemberian motivasi diberikan pada awal dan akhir pembelajaran demi mempertahankan semangat belajar peserta didik. Guru mendengarkan keresahan dan keinginan peserta didik agar terjalin ikatan yang baik antara guru dan peserta didik, dengan begitu motivasi yang disampaikan guru akan mudah diterima oleh peserta didik. (2) Peran guru sebagai inisiator dalam meningkatkan kualitas belajar pada pembelajaran daring yaitu dengan cara memanfaatkan teknologi informasi dan komunikasi dan media-media yang berkembang. Media belajar yang digunakan dalam menyampaikan pembelajaran berupa aplikasi antara lain Whatsapp, Facebook, Google Meet dan Google Form. Dengan menggunakan aplikasi-aplikasi ini dapat memudahkan guru dan peserta didik dalam berkomunikasi. Selain itu, guru dan peserta didik dapat belajar lebih banyak mengenal teknologi informasi dan komunikasi yang berkembang saat ini, sehingga guru dan peserta didik dapat mengikuti perkembangan zaman 


\section{DAFTAR PUSTAKA}

AM, Sudirman. Interaksi dan Motivasi Belajar Mengajar. Jakarta: Rajawali, 1990.

Abdul Karim dan Luluk Handayani. "Pengelolaan Open and Distance Learning Di TK Muslimat NU 41 Wuluhan Jember". GENIUS: Indonesian Journal of Early Childhood Education 1, no. 1 (June 2, 2020): https://genius.iain-jember.ac.id/index.php/gns/article/view/5.

AZ, Mulyana. Rahasia Menjadi Guru Hebat. Jakarta: Grasindo, 2010.

Cece Wijaya, dkk. Upaya Pembaharuan Dalam Pendidikan dan Pembaharuan dan Pengajaran. Bandung: Remaja Rosdakarya, 1992.

Hanifah Suhana dan Cucu. Konsep Strategi Pembelajaran. Bandung: PT. Rafika Aditama, 2010.

MedaYuliani, dkk. Pembelajaran Daring Untuk Pendidikan: Teori dan Penerapan. Yayasan Kita Menulis, 2020.

Observasi di Jember 2020.

Setyadi, Leken. Jadilah Guru Terbalik: Berfikir dan Bertindak Terbalik. Ponorogo: Uwais Isnprirasi Indonesia, 2019.

Slameto. Belajar dan Faktor-faktor yang Mempengaruhinya. Jakarta: Rineka Cipta, 2003.

Usmani, Moh. Uzer. Menjadi Guru Profesional. Bandung: Remaja Rosdakarya, 2001. 